89

\section{TWO-COURSE IBUPROFEN THERAPY TO INCREASE EFFECTIVENESS WHEN STANDARD THERAPY FAILED TO INDUCE PERMANENT DUCTUS CLOSURE.}

S DENIZOT ${ }^{l}$, G CAILLAUX-VARIN ${ }^{l}$, A KUSTER ${ }^{l}$, JC ROZÉl, V GOURNAY ${ }^{l}{ }^{I}$ DÉPARTEMENT DE PÉRINATOLOGIE, CHU (FRANCE)

Indomethacin is the conventional medical treatment of patent ductus arteriosus (PDA) in preterms, inducing ductal closure in about $70 \%$ of the patients. To increase this success rate, it has been recommended to prolong the standard 3-dose course by an additional 3-dose course. Ibuprofen is as effective as indomethacin with less renal side effects. In order to determine if, like indomethacin, the effectiveness of ibuprofen is increased by a second course, we retrospectively looked at the data of 1 newborns ( 5 male/ 6 female, mean gestational age $26.9 \pm 1.8$ weeks, mean birthweight $957 \pm 279$ grams who received 3 additional doses of ibuprofen after failure of the initial standard treatment. Standard ibuprofen treatment $(10 \mathrm{mg} / \mathrm{kg}$, followed by $5 \mathrm{mg} / \mathrm{kg}$ twice at 24 -hour intervals) was initiated at a mean age of $2.63 \pm 2.3$ days in patients with symptomatic PDA on echocardiogram. Recurrence of a hemodynamically significant PDA warranted retreatment by 3 additional doses (same dose regimen). Five patients (nonresponders) still had a wide patent ductus at the end of the first course and received the second course immediately. The remaining six patients (responders) had either a closed o constricted PDA at the end of the first course but had to be retreated 10.4 \pm 5.7 (5-19) days late because of secondary relapse. Two patients had mild and transient renal failure during the first course, one of which experienced severe and prolonged renal failure after the second course. Eventually, 7/11 infants ( $4 / 5$ nonresponders and $3 / 6$ responders) required surgical ligation at a mean age of $22 \pm 10$ days In conclusion, when standard ibuprofen therapy fails to induce permanent ductus closure, a second course may avoid surgery in about one third of the patients. However, if standard ibuprofen therapy fails to initiate ductal constriction, the chances of success of a second course seem rather scarce and surgery may be more appropriate.

\section{0}

PROTEIN INTAKE AFFECTS GLUCOSE METABOLISM PRIOR TO WEANING IN RAT PUPS.

C DES ROBERT ${ }^{l}, N$ LI $^{2}, L$ ZHANG ${ }^{2}, R$ CAICEDO ${ }^{2}, X K E^{3}, R L^{2}$ LANE ${ }^{3}, J$ NEU ${ }^{2}{ }^{1}$ UNIVERSITY MEDICAL CENTER (FRANCE) , ${ }^{2}$ UNIVERSITY OF FLORIDA, GAINESVILLE (USA), ${ }^{3}$ UNIVERSITY OF UTAH, SALT LAKE CITY (USA)

Background: Fetal malnutrition can lead to a metabolic syndrome in adulthood. Early postnatal nutrition is probably also involved in metabolic programming. Epigenetic mechanisms could be responsible. Protein intake is frequently increased for small babies in order to attain catch-up growth. Short and long term effects of this practice at this critical period of life are not known.

Hypothesis: Protein overfeeding during the neonatal period could lead to modifications of glucose metabolism and epigenetic changes.

Methods: Rat pups were randomized in 3 experimental groups receiving different diets via gastrostomy with 50\% (G50\%), 100\% (G100\%) and 130\% (G130\%) of usual mother fed amount of protein from D7 to D15. The control group consisted of mother-fed pups (MF). At D15, the pups were sacrificed. Tissues were harvested for morphometry, epigenetic and biochemical analysis. Plasm insulin/glucose ratio was calculated. Epigenetic markers were studied in the brain: quantification of histone $\mathrm{H} 3$ acetylation and methylation, and of mRNA levels of the glucocorticoid receptors (GR).

Results: There was a trend toward higher insulin/glucose ratio in the $\mathrm{G} 130 \%$, and lower in the G50\%.In G130\% compared to $\mathrm{G} 100 \%$ as control, $\mathrm{H} 3 / \mathrm{K} 14$ acetylation increased $(\mathrm{p}<0.05)$. In contrast, $\mathrm{H} 3 / \mathrm{K} 9$ acetylation decreased $(\mathrm{p}<0.01)$ and $\mathrm{H} 3 / \mathrm{K} 9$ di- and trimethylation increased $(\mathrm{p}<0.01)$. mRNA levels of GR exon 1 isoforms 1.5 and 1.6 were decreased $(\mathrm{p}<0.01)$. Total body weight, liver and kidney weights did not differ among the groups, whereas brain weight per total body weight was greatest in the group fed $50 \%$ protein $(\mathrm{p}<0.005)$. There was no correlation between the pancreatic isle area and the insulin/glucose ratio.

Conclusion: These data suggest a trend toward glucose intolerance in infant rats receiving high protein diets, associated with epigenetic changes.

\section{1}

DOES PROTEIN INTAKE DURING INFANCY PROGRAM FOR GLUCOSE TOLERANCE IN ADULTHOOD?

C DES ROBERT ${ }^{l}, N L^{2}, L$ ZHANG ${ }^{2}, R$ LANE ${ }^{3}, J$ NEU $U^{2}{ }^{1}$ UNIVERSITY MEDICAL CENTER (FRANCE), ${ }^{2}$ UNIVERSITY OF FLORIDA, GAINESVILLE (USA), ${ }^{3}$ UNIVERSITY OF UTAH, SALT LAKE CITY (USA)

Background: Fetal malnutrition can program for metabolic syndrome in adulthood. Postnatal nutrition probably also results in metabolic programming. Protein intakes for premature babies and newborns with IUGR are relatively high, in order to attain catch-up growth. Long term consequences of this high supply at this critical period of life are not known.

Hypothesis: high protein intake during the preweaning period will result in long term metabolic consequences.

Methods: Rat pups were placed at birth in normal or expanded litters in order to create extra-uterine growth retardation. They were fed by gastrostomy from D7 to D15 and randomized into 3 groups with $50 \%, 100 \%$ and $130 \%$ of usual mother fed amount of protein. Mother-fed pups (MF) served as reference controls. At D15, the pups were placed back with their mothers. Glucose tolerance tests were performed at D200. The weight was followed. Food consumption was also evaluated. The rats were sacrificed at D200 and the organs were harvested for morphometry and biochemical analyses.

Results: $n=13$ females in normal litter group, $n=21$ in litter expanded group. The weight of G50\% was significantly less at D15, but not at D200. There was a trend to glucose intolerance with highe insulin/glucose ratio and basal insulin for G130\% in the normal litter group, and in G130\% and MF in the litter expanded group. The food consumption was not different among groups.

Conclusion: High protein intakes during infancy may lead to insulin resistance in adulthood. Catch-up diets may also lead to insulin resistance in adulthood.
92

MEDICATION ERRORS ON THE NEONATAL UNIT

CDEWHURST ${ }^{l}$ D ANAND ${ }^{l}$ M HESSELING ${ }^{l}$ P SETTLE ${ }^{l}$, H PARRY $Y^{l}$, N SUBHEDAR ${ }^{l}$ NEONATAL ICU, LIVERPOOL WOMENS HOSPITAL (UK)

Background: Medication errors are common in health care and have the potential to cause significant morbidity and mortality. There is little information regarding the nature, frequency and severity of such errors specifically in the neonatal population.

Aims/Objectives: To quantify (1) the frequency of medication errors, (2) identify the stage of the medication process where such errors occur and (3) describe the risk severity associated with each error

Methods: All adverse clinical incidents and near-misses related to the medication process were identified from an Adverse Clinical Event (ACE) computer database during 2004. Errors were categorised by the stage of the medication process during which they occurred and the seriousness of risk posed. We also devised a new system of reporting where staff reported all medication errors anonymously. Reporting rates were compared with our traditional ACE reporting system to determine the extent of under-reporting of medication errors.

Results: A total of 505 ACEs were reported during the one year study period; of these, 109 (22\%) were recorded as medication errors. The majority of medication errors were classified as near-mis events $(89 \%)$ rather than adverse clinical incidents, and as low/very low risk (91\%). Errors occurred most commonly in the ordering (34\%) and administration (42\%) steps of the medication process Anonymous reporting led to 39 medication errors being highlighted during a one-week period (equivalent to 2028/year), suggesting that the true frequency of medication errors may be far higher than that identified by voluntary reporting through the ACE reporting system.

Conclusions: Medication errors are common in neonatal care, but most are near-misses rather than adverse clinical incidents. Ascertainment of such errors using a voluntary ACE reporting system is likely to result in a gross underestimate of the true error rate. We speculate that strategies that minimise ordering/administration errors may have the greatest impact in enhancing patient safety.

\section{3}

10 YEARS SCREENING FOR RETINOPATHY OF PREMATURITY (ROP): DIFFERENCES IN SMALL (SGA) AND APPROPRIATELY (AGA) GROWN INFANTS.

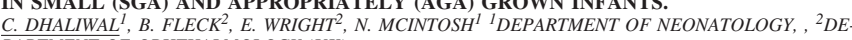
PARTMENT OF OPHTHALMOLOGY (UK)

BACKGROUND INFANTS BORN SGA HAVE BEEN REPORTED TO BE AT INCREASED RISK OF DEVELOPING SIGHT-THREATENING ROP(1)

OBJECTIVE TO COMPARE THE PREVALENCE OF ROP IN SGA (BIRTH WEIGHT $<10$ TH PERCENTILE) AND AGA INFANTS SCREENED AT THE SOUTH EAST SCOTLAND REGIONAL NEONATAL UNIT IN EDINBURGH FROM JANUARY 1993-JANUARY 2003.

METHODS ALL INFANTS IN THIS TERTIARY REFERRAL NEONATAL UNIT WITH A GESTATIONAL AGE AT BIRTH OF $<32$ WEEKS OR BIRTH WEIGHT OF $<1500$ G WERE SCREENED; FIRST AT POSTNATAL AGE OF 5-6 WEEKS AND THEN AT LEAST EVERY SECOND WEEK UNTIL FULL RETINAL VASCULARISATION. SCREENING WAS CARRIED OUT BY 2 DEDICATED PAEDIATRIC OPHTHALMOLOGISTS (EW AND BF) USING INDIRECT OPHTHALMOSCOPY AND RETINOPATHY WAS GRADED BY INTERNATIONAL ROP (3). THE GRADE OF ROP. PRESENCE OF ROP AND ROP REQUIRING LASER TREATMENT WERE ROP (3). THE GRADE OF ROP, PRESENCE OF ROP AND ROP REQUIR

RESULTS 830 INFANTS (208 [25\% SGA]) WERE SCREENED, 38 (18\%) SGA AND $127 / 622(20 \%)$ AGA INFANTS HAD ROP. NO BABY OF GESTATION $>28$ WEEKS REQUIRED TREATMENT FOR ROP.

\begin{tabular}{|c|c|}
\hline SIG LEVEL(p) & 25-(WKS GEST)-26 $-27-28-29$ \\
\hline GRADE ROP & $0.12-0.10-0.00^{*}-0.02 *-0.47$ \\
\hline PRESENCE ROP & $0.15-0.05 *-0.00 *-0.02 *-0.47$ \\
\hline LASER ROP & $0.69-0.76-0.16-0.21-{ }_{-1 / I I}$ \\
\hline
\end{tabular}

*SIGNIFICANTLY GREATER PROPORTION OF SGA INFANTS

CONCLUSIONS SGA INFANTS BORN $<28$ WEEKS GESTATION HAD AN INCREASED RISK OF DEVELOPING ROP AND ALTHOUGH THERE WAS A TREND TO WORSE ROP, NO MORE REQUIRED TREATMENT.

REFERENCES 1)PEDIATRICS 1997;100(2):E4 2)PEDIATRICS 1984;74:127-133 3)ARCH OPHTHALMOLOGY 1988;106:471-479

94

ACCESS TO OBSTETRIC AND NEONATAL CARE FOR VERY PRETERM DELIVERIES IN CENTRAL ITALY

D DI LALLO ${ }^{1}, M$ BARBOLINI ${ }^{1}, R$ AGOSTINO ${ }^{2}$, S SANTONI $^{1}$, G GUASTICCHI ${ }^{1}{ }^{1}$ AGENCY FOR PUBLIC HEALTH LAZIO REGION, ${ }^{2}$ DEPARTMENT NEONATOLOGY, S.G.CALIBITA HOSPITAL (ITALY)

Introduction. The aim of the study was to analyse the access to obstetric and neonatal care for very preterm deliveries in an Italian region, as part of a European project (MOSAIC) involving ten countries.

Methods. During 2003, data were collected in Lazio region on Termination of Pregnancy (TOP), Foetal Deaths (FD) and Live Births (LB). Very preterm (VP) cases included TOP and FD of gestational age $22-31$ wks, LB of $22-31$ wks or birth weight $<=1500$ gr. All the 58 units were classified by three level of care ( $n=34$ level $1, n=12$ level 2 and $n=12$ level 3 ). Data on deliveries from the entire population were derived from the regional hospital discharge database. A total of $770 \mathrm{VP}$ cases were collected: 102 TOP, 113 FD and 555 LB, compared to 15188 TOP, 8901 FD and 51727 $\mathrm{LB}$ registered in the total population.

Results. The percentage of VP cases occurred in level 3 units was respectively of $71,6 \%$ for TOP $72.6 \%$ for FD and $87.7 \%$ for LB, compared to $52.1 \%, 36.9 \%$ and $42.7 \%$ observed for the total population in the same level of care. Among the 510 women who had a foetal death during labour or a live birth, $65,9 \%$ had received antenal steroids. The utilization of prenatal steroids is higher in leve 3 units $(71.6 \%)$ compared to level 1 and level 2 units (40\% and 18.9\%). The transfer rate of very preterm LB from level 1 and 2 to level 3 units was 93.9\%. Among the $487 \mathrm{LB}$ cases occurred in level 3 the transfer rate to other units of the same level was $20.3 \%(\mathrm{n}=97)$, compared to $1.4 \%$ observed 3 the transfer rate to other units of the san
within level 3 units in the total population.

Conclusions. The study indicates that effort to concentrate the very preterm births in level 3 units has been effective. The high transfer rate within level 3 units, mainly due to bed shortage and to surgical treatment, indicates the need for improvement of the services and the organization. An appropriate evaluation of these results will include the analysis of the services in term of morbidity and mortality outcomes. 